\title{
Intramedullary Fixation Does Not Cause a Large Amount of Hidden Blood Loss in Elderly Patients with Intertrochanteric Fractures
}

This article was published in the following Dove Press journal:

Clinical Interventions in Aging

Junfei Guo
Yingze Zhang
Zhiyong Hou

'Department of Orthopedic Surgery, Third Hospital of Hebei Medical University, Shijiazhuang, Hebei, 05005 I, People's Republic of China; ${ }^{2} \mathrm{NHC}$ Key Laboratory of Intelligent Orthopaedic Equipment (The Third Hospital of Hebei Medical University), Shijiazhuang, People's Republic of China; ${ }^{3}$ Chinese Academy of Engineering, Beijing, 100088, People's Republic of China
Correspondence: Zhiyong Hou Third Hospital of Hebei Medical University, Department of Orthopaedic Surgery, Shijiazhuang, Hebei, 05005I, People's Republic of China

Tel +86- |8533| | 2800

Fax +86-03II-8702362

Email drzyhou@gmail.com
Purpose: Controversy remains around intramedullary fixation of intertrochanteric fractures in elderly patients when considering hidden blood loss (HBL). However, whether treating the fractures with intramedullary fixation causes a large amount of HBL is not known.

Patients and Methods: In this retrospective cohort study, 1,017 consecutive patients aged $\geq 65$ years with acute intertrochanteric fractures were included and assigned to three groups (non-operative group, delayed surgery group, and acute surgery group) between July 2013 and January 2018. The data of patients' demographics, injury-related data, operation-related data, comorbidities, perioperative hemoglobin values, transfusion data and serial of HBL calculated during hospitalization were collected and compared among three groups. All independent variables were further analyzed by multiple linear regression to evaluate the influential factors of HBL. A long-term follow-up was conducted and survival analysis was performed for all individuals.

Results: Our results showed that fixation by proximal femoral nail anti-rotation for intertrochanteric fracture has been estimated to contribute $11-34 \%$ of the increase of HBL during hospitalization and it does not increase the allogeneic transfusion rate. For HBL, male patients, unstable fracture, and blood transfusion may have strong influences. Surgical delay was associated with longer time from injury to hospital admission, higher ASAgrade, and comorbidities such as diabetes and coronary heart disease. Survival analysis revealed that mortality increased in patients with conservative treatment, where a rapid decline was found in the first year, especially in the 90 days after injury. A higher mortality rate was also obtained in patients with surgery delay than acute surgery patients.

Conclusion: In conclusion, HBL is the main component of total blood loss and it is more likely to result from the initial trauma rather than the surgery. Intertrochanteric fracture treated by intramedullary fixation does not cause a large amount of HBL.

Keywords: hidden blood loss, intertrochanteric fracture, elderly, multiple linear regression, survival analysis

\section{Introduction}

The incidence of fractures in the trochanteric area has risen with the increasing numbers of elderly persons with osteoporosis. ${ }^{1}$ It is estimated that as many as 1.7 million people worldwide suffer from hip fractures each year, and this number has been increasing by about $25 \%$ each decade. ${ }^{2}$

Nowadays, intramedullary fixation (IMF) with proximal femoral nail antirotation (PFNA) has become the preferred internal fixation for these fractures, especially in osteoporotic bone. ${ }^{1}$ However, the issue of blood loss in 
intertrochanteric fractures has become more and more concerned, which varied from $612 \mathrm{~mL}$ to $1,861 \mathrm{~mL}$, most of which is hidden blood loss (HBL). ${ }^{3}$ Foss and Kehlet $^{3}$ concluded that HBL was substantial, with an excess of up to 6-times that observed during the surgical procedure.

The main objective of this study was to investigate whether surgical treatment by IMF leads to a large amount of HBL compared to the initial trauma itself in patients with intertrochanteric fractures. We hypothesized that IMF does not cause a large amount of HBL.

\section{Patients and Methods}

\section{Patients and Groups}

A retrospective analysis of all patients presenting with an intertrochanteric fracture was conducted at a single Level I trauma center between July 2013 and January 2018. This study was approved by the institutional internal review board of the participating institution in compliance with the Declaration of Helsinki and consent were waived for its retrospective nature. Patients 65 years or older presenting with fresh fracture (with an admission delay less than 48 hours), with hemoglobin ( $\mathrm{Hb})$ and hematocrit (Hct) record at admission and a series of pre- and postoperative records, treated with closed reduction and internal fixation by PFNA if they undergo surgery, and who received a minimum of 2-years follow-up were included. Patients with multiple fractures or injuries, with pathological or open fracture, who underwent previous operations on the hip area, appeared with typical hemolytic reaction after blood transfusions, and who were suffering from gastrointestinal hemorrhage and perioperative hematological disease were excluded. Patients were retrospectively assigned to three groups: those taking conservative treatment were placed in Group A; those with surgery delay of more than 7 days after the injury were placed in Group B (due to comorbidities and other medical causes); and those who underwent operations within 7 days were placed in Group C.

\section{Data Collection}

The medical records of patients' demographics including age, gender, and body mass index (BMI); injury-related data including fracture type according to the AO/OTA classification $^{4}$ and injury mechanism; operation-related data including American Society of Anesthesiologists (ASA, six grade), whether traction before surgery, duration of operation, method of anesthesia (general anesthesia, spinal anesthesia, or combined spinal-epidural anesthesia), and volume of intra-operative blood loss; other records of comorbidities, serial perioperative $\mathrm{Hct}$ and $\mathrm{Hb}$ values, transfusion data (whether receive blood transfusions and blood transfusion volume), and serial HBL calculated during hospitalization were extracted, verified, and confirmed for each patient by medical and radiological records. All electronic data were evaluated by two orthopedic surgeons not involved in patients' care, and if the consequences differed greatly, a discussion was needed. The comorbidities were recorded as hypertension, diabetes, coronary heart disease, carotid plaque/atherosclerosis, delirium, cerebrovascular disease, arrhythmia, myocardial infarction, heart failure, valvular heart disease, lung disease, respiratory failure, hepatobiliary disease, digestive system disease, renal dysfunction, tumor, hypoproteinemia, and deep venous thrombosis (DVT). The participants' survival status and date of death were collected during the followup. The follow-up started from the enrollment to the cohort and ended on the date of death or the end of the study. The endpoint events were defined as all reasons of death or the end of the study, whichever was earlier.

Since a number of patients could not be weighed on a conventional scale upon admission, their weight and height were estimated by the orthopedic surgeon supported by the patients' own information. ${ }^{5}$ Based on BMI, patients were divided into normal $\left(\mathrm{BMI}<24 \mathrm{~kg} / \mathrm{m}^{2}\right)$, overweight $\left(24 \leq \mathrm{BMI}<28 \mathrm{~kg} / \mathrm{m}^{2}\right)$, and obese $\left(\mathrm{BMI} \geq 28 \mathrm{~kg} / \mathrm{m}^{2}\right)$.

\section{Surgery Treatment and Clinical Care}

All surgeries using IMF were performed by one group of orthopedic surgeons. All of the patients received national guidelines for the surgical techniques via supine position and the length of incision was within a range of 3-5 cm. According to preoperative measurement results of $\mathrm{CT}$, the blade of PFNA with appropriate size was hammered directly into the proximal femur. In order to reduce intraoperative bleeding, hypotension was maintained and returned to normal blood pressure before the end of surgery. Complete hemostasis and suture in layer carefully were performed at the end of surgery. All patients received first- or second-generation cephalosporins as prophylaxis for infection and low molecular-weight heparin, as antiplatelet therapy, was routinely injected subcutaneously to prevent DVT. Patients were encouraged to early full weight bearing with the necessary assistance of their 
family members and the follow-up was carried out in the orthopedic outpatient clinic.

\section{HBL Calculation Methods}

The levels of $\mathrm{Hct} / \mathrm{Hb}$ from continuous blood routine were measured on admission, with an interval of 1 or 2 days pre- and post-operative until the day patients left hospital, as well as following blood transfusions, to calculate serial $\mathrm{HBL}$. Blood transfusions were given when $\mathrm{Hb}$ levels dropped below $80 \mathrm{~g} / \mathrm{L}^{6,7}$ at any point during their hospitalization or when patients were symptomatic. The total volume of blood transfusions was recorded. Intraoperative and post-operative blood loss were also recorded. The estimated patient blood volume (PBV) can be calculated using the formula as follows according to gender and height: ${ }^{8}$

PBV $(\mathrm{L})$ for men $=$ height $(\mathrm{m}) 3 \times 0.3669+$ weight $(\mathrm{kg})$ $\times 0.03219+0.6041$ and,

PBV (L) for women $=$ height $(\mathrm{m}) 3 \times 0.3561+$ weight $(\mathrm{kg}) \times 0.03308+0.1833$.

There were no abnormalities found among the patients in ion concentrations such as potassium, sodium, and chlorine in peri-operation, and the blood volume of each patient was in the normal range, hence it can be assumed that the total blood volume would be the same on whole hospitalization. All red blood cell transfusions were assumed to contain the same number of cells and a unit of red blood cells is approximately $200 \mathrm{~mL}$.

The total red cell loss volume (TRCL) was calculated by multiplying PBV by the change of $\mathrm{Hct}$ or $\mathrm{Hb}$ and the total perioperative blood loss (TBL) was calculated as: ${ }^{9}$

$\mathrm{TBL}=\mathrm{TRCL} /$ Hctave $=\mathrm{PBV} \times($ Hctadm - Hctx $) /$ Hctave.

Or TBL $=\mathrm{PBV} \times(\mathrm{Hbadm}-\mathrm{Hbx}) /$ Hbave.

Then, the HBL was was further calculated:

$\mathrm{HBL}=\mathrm{TRCL} / \mathrm{Hct}$ average - dominant (measured) blood loss + transfusion volume.

A factor of 0.9 was corrected for $\mathrm{Hb}$ level of admission in order to simulate the potential impact of dehydration on admission. $^{3}$

\section{Statistical Analysis}

The distributions of all variables were evaluated for normality by using the Shapiro-Wilk test. Data satisfying normality were presented as the mean and standard deviation $( \pm \mathrm{SD})$. Data that did not meet normality were presented as median (interquartile range). Count data were expressed in percentages (\%). The tests for significant differences between normally distributed data samples were performed using Student's $t$-test or ANOVA for independent samples while the tests for significant differences between non-normal data were done with the Wilcoxon rank-sum test or Kruskal-Wallis $H$-test. All perioperative data were analyzed for univariate influence among different groups. Multiple linear regression was performed on the total number of cases to evaluate the influential factors of HBL using all independent variables assumed to be potentially causative. In the multi-category variables, ASA grade I, normal BMI, general anesthesia, no DVT, and patients in the non-operative group (group A) were chosen as standard, others were converted into dummy variables. The survival analysis was performed for all individuals and conducted using Kaplan-Meier methods. The Log rank test was used for comparing Kaplan-Meier survival curves among the three groups. All data analyses were performed using IBM SPSS Statistics for Windows, version 26.0 (IBM, Armonk, $\mathrm{NY}$ ). The level of significance was set at $p<0.05$.

\section{Results}

\section{Demographic and Injury-Related Data of Study Participants}

From July 2013 and January 2018, a total of 1,799 consecutive patients presenting with fresh intertrochanteric fracture were screened and assessed for eligibility in this study. A total of 663 patients were eliminated by exclusion criteria (see Figure 1). Finally, 1,017 patients, including 133 in the non-operative group (group A), 250 in the delayed surgery group (group B), and 634 in the acute surgery group (group C) met our inclusion and exclusion criteria. Demographic and injury-related data of study patients are summarized in Table 1. The majority of patients were women $(66.1 \%)$ with an average age of $78.4 \pm 8.4$ years. There were $633(62.2 \%)$ patients with stable fractures and most (97.4\%) were resulting from falls. The results revealed no significant difference in gender, age, BMI, fracture type, or injury mechanism among the three groups $(p>0.05)$.

\section{Comparison of Comorbidities, Operation-Related Data, Hidden Blood Loss, Hb Levels, and Transfusion Data}

Table 2 shows the statistical distribution of comorbidities and significant differences were found among groups in diabetes, coronary heart disease, cerebrovascular disease, 


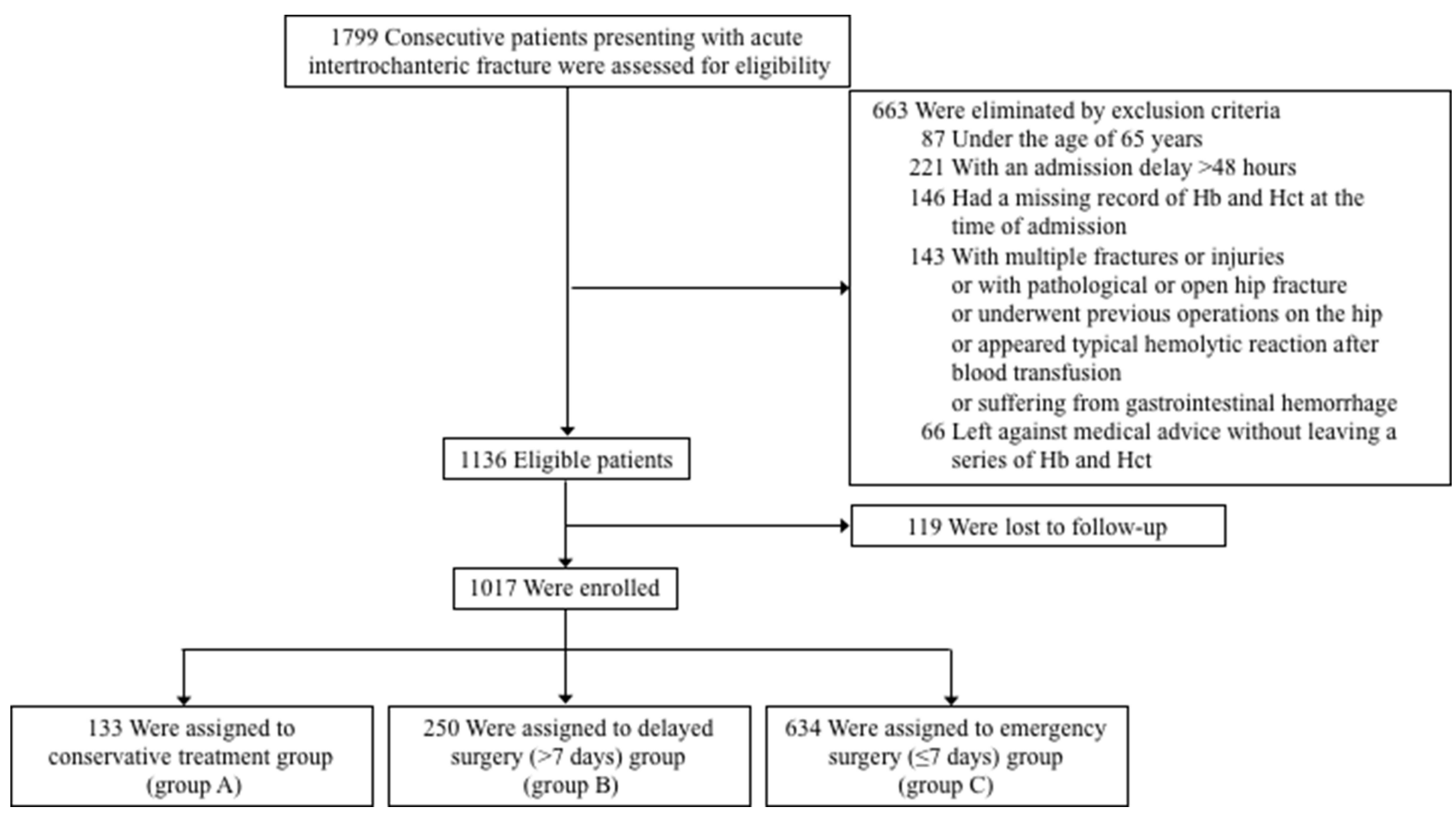

Figure I Flow diagram of included patients.

arrhythmia, heart failure, lung disease, and respiratory failure $(p<0.05)$. Table 3 reveals significant differences observed in HBLmax (maximum HBL calculated during the whole hospitalization), $\mathrm{Hb}$ value of admission, the lowest record of $\mathrm{Hb}$ during hospitalization, $\mathrm{Hb}$ decrease between admission/the lowest and between admission/discharge, and blood transfusion volume among three groups. The median HBLmax in groups $\mathrm{A}, \mathrm{B}$, and $\mathrm{C}$ was $584.1 \mathrm{~mL}, \quad 780.8 \mathrm{~mL}$, and $649.2 \mathrm{~mL}$, respectively $(p<0.001)$. For the decreased $\mathrm{Hb}$ content, patients in the two surgery groups had a little larger $\mathrm{Hb}$ decrease (36.5-$39.1 \%$ ) between admission/lowest record compared to that of the non-operative patients. However, the mean $\mathrm{Hb}$ level of discharge did not differ significantly $(p>0.05)$. Less than $70 \%$ of patients in group A had an ASA grade III and below, in comparison with $87.2 \%$ in group $\mathrm{B}$ and $89.5 \%$ in group $\mathrm{C}(p<0.001)$. In group $\mathrm{C}, 16.6 \%$ of patients performed bone traction before surgery, which was less than other groups $(p<0.001)$. Despite attaining statistical significance, the difference of duration of operation $(99.6 \pm 34.0$ minutes for group C vs $105.4 \pm 35.6$ minutes for group B, $p=0.025$ ) in the two operation groups is so small that it might not be of clinical relevance. However, patients in group B were twice as large as in group C (200 mL vs $100 \mathrm{~mL}, p=0.001$ ) for the amount of intra-operative blood loss. Regarding blood transfusions, the median volume of patients in group A and group C was significantly less $(p=0.001)$ than that of group B. However, there was no significant difference in transfusion rate $(p>0.05)$ (Table 3).

\section{Analysis of Possible Influencing Factors of Hidden Blood Loss}

To examine the association between HBLmax and all factors that it could causatively be related to, we performed multiple linear regression on total patients. As shown in Table 4, factors associated with the increased HBLmax were male patients $(p<0.001)$, unstable fracture $(p<0.001)$, blood transfusion volume $(p<0.001)$, and BMI (overweight, $p=0.027$; obesity, $p=0.019$ ), where the former three had more risk of increased HBLmax as compared to BMI. As a result, the mean contribution to HBLmax was $198 \mathrm{~mL}$ in male patients, $197 \mathrm{~mL}$ in unstable fracture, and $22 \mathrm{~mL}$ per unit of blood transfusion, respectively. It appeared that other factors were not significantly correlated with HBLmax (Table 4).

\section{Survival Analysis}

Of all 1,017 patients, 306 (30.1\%) were dead, 72 (54.1\%) from the nonoperative group, $85(34.0 \%)$ from the delayed 
Table I Demographic and Injury-Related Data of the Study Participants

\begin{tabular}{|c|c|c|c|c|c|}
\hline Characteristics & $\begin{array}{c}\text { Non-Operative } \\
\text { Group (Group A) } \\
(n=133)\end{array}$ & $\begin{array}{l}\text { Delayed Surgery } \\
\text { Group (Group B) } \\
\quad(n=250)\end{array}$ & $\begin{array}{c}\text { Acute Surgery } \\
\text { Group (Group C) } \\
(n=634)\end{array}$ & Total $(n=10 \mid 7)$ & $p$-value ${ }^{a}$ \\
\hline \multicolumn{6}{|l|}{ Demographic } \\
\hline Gender, n (\%) & & & & & 0.119 \\
\hline Male & 50 (37.6\%) & 95 (38.0\%) & $200(31.5 \%)$ & 345 (33.9\%) & \\
\hline Female & $83(62.4 \%)$ & I 55 (62.0\%) & 434 (68.5\%) & $672(66.1 \%)$ & \\
\hline Age,years & $79.5 \pm 8.0$ & $78.3 \pm 8.4$ & $78.3 \pm 8.5$ & $78.4 \pm 8.4$ & 0.275 \\
\hline BMI, n (\%) & & & & & 0.458 \\
\hline Normal $\left(B M I<24 \mathrm{~kg} / \mathrm{m}^{2}\right)$ & 89 (66.9\%) & I 48 (59.2\%) & 368 (58.0\%) & 605 (59.5\%) & \\
\hline Overweight & $34(25.6 \%)$ & 79 (31.6\%) & 204 (32.2\%) & 317 (3I.2\%) & \\
\hline$\left(24 \leq \mathrm{BM}<<28 \mathrm{~kg} / \mathrm{m}^{2}\right)$ & & & & & \\
\hline Obesity $\left(\mathrm{BMI} \geq 28 \mathrm{~kg} / \mathrm{m}^{2}\right)$ & $10(7.5 \%)$ & $23(9.2 \%)$ & $62(9.8 \%)$ & $95(9.3 \%)$ & \\
\hline \multicolumn{6}{|l|}{ Injury-related data } \\
\hline Fracture type, n (\%) & & & & & 0.283 \\
\hline Stable (AI.I-A2.I) & 91 (68.4\%) & $152(60.8 \%)$ & $390(61.5 \%)$ & $633(62.2 \%)$ & \\
\hline Unstable (A2.2-A3.3) & 42 (31.6\%) & 98 (39.2\%) & 244 (38.5\%) & $384(37.8 \%)$ & \\
\hline Injury mechanism, n (\%) & & & & & 0.484 \\
\hline Fall injury & $130(97.7 \%)$ & $24 \mathrm{I}(96.4 \%)$ & $620(97.8 \%)$ & 991 (97.4\%) & \\
\hline Violent injury & $3(2.3 \%)$ & $9(3.6 \%)$ & $14(2.2 \%)$ & $26(2.6 \%)$ & \\
\hline
\end{tabular}

Notes: Plus-minus values are means \pm SD; ${ }^{a}$ In gender, fracture type, injury mechanism, and BMI, $p$-values are the results of pearson chi-square tests. In age, $p$-value is the result of ANOVA test on mean.

Abbreviations: NA, not available; BMI, body mass index; IQR, interquartile range.

surgery group, and 149 (23.5\%) from the acute surgery group, respectively. The Kaplan-Meier survival curve of patients without surgery was significantly lower than that of surgical patients (Figure 2, $p<0.001$, log-rank). Patients in the nonoperative group had a rapid decline of cumulative survival rate in the first year, especially in the 3 months after injury, while that of surgical patients gradually decreased from 1 to 4 years after injury, and stabilized after that. Further comparison of the two surgical groups showed that the cumulative survival rate of patients with acute surgery was higher than that of delayed surgery patients $(p=0.001, \log$-rank).

\section{Discussion}

Regarding our results, we found intertrochanteric fracture treated by intramedullary fixation represents only a small proportion of the increase of HBL and does not increase the allogeneic transfusion rate among the three groups of patients. The peak of HBL appeared at a certain time after the injury. Diabetes, coronary heart disease, cerebrovascular disease, arrhythmia, heart failure, severe lung disease, and respiratory failure were identified to possibly have influences on the surgery delay in this study. Male patients, unstable fracture, and blood transfusion may have strong influences on HBL.

Early surgery, as the most effective treatment for these elderly patients, has been recommended for a number of reasons; ${ }^{10}$ however, the influence of surgical delay we studied may not be a prospective study due to its ethical violations. The selection bias of patients who had delayed surgery or received non-operative treatment were not based on random experience, but on the serious comorbidities as well as referring to the anesthesiologist's consultation. To the best of our knowledge, operating within 24-48 hours remains a challenge for clinical surgeons since the delay is necessary management of comorbidities and acceptable for stabilizing geriatric patients. Based on the research of Buse et al, ${ }^{11}$ in the majority of institutions worldwide, patients with femur fracture were operated on with a delay of more than 24 hours. Moreover, White et $\mathrm{al}^{12}$ reported that in the UK, $42 \%$ of operations were delayed with admission to operation time $>48$ hours: $51 \%$ for organizational; $44 \%$ for medical; and 4\% for anesthetic reasons. The current situation in China is that it takes time to transfer patients to the superior specialist hospitals and to deal with comorbidities, causing a large proportion of 
Table 2 Comorbidities of the Study Participants

\begin{tabular}{|c|c|c|c|c|c|}
\hline Comorbidities & $\begin{array}{l}\text { Non-Operative Group } \\
\text { (Group A) }(n=133)\end{array}$ & $\begin{array}{l}\text { Delayed Surgery Group } \\
\text { (Group B) }(n=250)\end{array}$ & $\begin{array}{l}\text { Acute Surgery Group } \\
\text { (Group C) }(n=634)\end{array}$ & Total $(n=1,017)$ & $p$-value ${ }^{\text {a }}$ \\
\hline $\begin{array}{l}\text { Hypertension } \\
\text { Yes } \\
\text { No }\end{array}$ & $\begin{array}{l}62(46.6 \%) \\
7 I(53.4 \%)\end{array}$ & $\begin{array}{l}\text { I } 35(54.0 \%) \\
\text { II }(46.0 \%)\end{array}$ & $\begin{array}{l}309(48.7 \%) \\
325(51.3 \%)\end{array}$ & $\begin{array}{l}506(49.8 \%) \\
511(50.2 \%)\end{array}$ & 0.274 \\
\hline $\begin{array}{l}\text { Diabetes } \\
\text { Yes } \\
\text { No }\end{array}$ & $\begin{array}{l}36(27.1 \%) \\
97(72.9 \%)\end{array}$ & $\begin{array}{l}81(32.4 \%) \\
169(67.6 \%)\end{array}$ & $\begin{array}{l}134(21.1 \%) \\
500(78.9 \%)\end{array}$ & $\begin{array}{l}25 \mathrm{I}(24.7 \%) \\
766(75.3 \%)\end{array}$ & $0.002 *$ \\
\hline $\begin{array}{l}\text { Coronary heart } \\
\text { disease } \\
\text { Yes } \\
\text { No }\end{array}$ & $\begin{array}{l}43(32.3 \%) \\
90(67.7 \%)\end{array}$ & $\begin{array}{l}82(32.8 \%) \\
168(67.2 \%)\end{array}$ & $\begin{array}{l}139(21.9 \%) \\
495(78.1 \%)\end{array}$ & $\begin{array}{l}264(26.0 \%) \\
753(74.0 \%)\end{array}$ & $0.001 *$ \\
\hline $\begin{array}{l}\text { Carotid plaquel } \\
\text { atherosclerosis } \\
\text { Yes } \\
\text { No }\end{array}$ & $\begin{array}{l}41(30.8 \%) \\
92(69.2 \%)\end{array}$ & $\begin{array}{l}78(31.2 \%) \\
172(68.8 \%)\end{array}$ & $\begin{array}{l}192(30.3 \%) \\
442(69.7 \%)\end{array}$ & $\begin{array}{l}311(30.6 \%) \\
706(69.4 \%)\end{array}$ & 0.963 \\
\hline $\begin{array}{l}\text { Cerebrovascular } \\
\text { disease } \\
\text { Yes } \\
\text { No }\end{array}$ & $\begin{array}{l}53(39.8 \%) \\
80(60.2 \%)\end{array}$ & $\begin{array}{l}91(36.4 \%) \\
159(63.6 \%)\end{array}$ & $\begin{array}{l}187(29.5 \%) \\
447(70.5 \%)\end{array}$ & $\begin{array}{l}331(32.5 \%) \\
686(67.5 \%)\end{array}$ & $0.022 *$ \\
\hline $\begin{array}{l}\text { Delirium } \\
\text { Yes } \\
\text { No }\end{array}$ & $\begin{array}{c}9(6.8 \%) \\
124(93.2 \%)\end{array}$ & $\begin{array}{c}\text { II (4.4\%) } \\
239(95.6 \%)\end{array}$ & $\begin{array}{c}37(5.8 \%) \\
597(94.2 \%)\end{array}$ & $\begin{array}{c}57(5.6 \%) \\
960(94.4 \%)\end{array}$ & 0.580 \\
\hline $\begin{array}{l}\text { Arrhythmia } \\
\text { Yes } \\
\text { No }\end{array}$ & $\begin{array}{l}30(22.6 \%) \\
103(77.4 \%)\end{array}$ & $\begin{array}{c}34(13.6 \%) \\
216(86.4 \%)\end{array}$ & $\begin{array}{c}69(10.9 \%) \\
565(89.1 \%)\end{array}$ & $\begin{array}{l}133(13.1 \%) \\
884(86.9 \%)\end{array}$ & $0.00 I^{*}$ \\
\hline $\begin{array}{l}\text { Myocardial } \\
\text { infarction } \\
\text { Yes } \\
\text { No }\end{array}$ & $\begin{array}{c}6(4.5 \%) \\
127(95.5 \%)\end{array}$ & $\begin{array}{c}\text { II (4.4\%) } \\
239(95.6 \%)\end{array}$ & $\begin{array}{c}16(2.5 \%) \\
618(97.5 \%)\end{array}$ & $\begin{array}{c}33(3.2 \%) \\
984(96.8 \%)\end{array}$ & 0.248 \\
\hline $\begin{array}{l}\text { Heart failure } \\
\text { Yes } \\
\text { No }\end{array}$ & $\begin{array}{l}16(12.0 \%) \\
117(88.0 \%)\end{array}$ & $\begin{array}{c}12(4.8 \%) \\
238(95.2 \%)\end{array}$ & $\begin{array}{c}12(1.9 \%) \\
622(98.1 \%)\end{array}$ & $\begin{array}{c}40(3.9 \%) \\
977(96.1 \%)\end{array}$ & $<0.001 *$ \\
\hline $\begin{array}{l}\text { Valvular heart } \\
\text { disease } \\
\text { Yes } \\
\text { No }\end{array}$ & $\begin{array}{c}3(2.3 \%) \\
130(97.7 \%)\end{array}$ & $\begin{array}{c}8(3.2 \%) \\
242(96.8 \%)\end{array}$ & $\begin{array}{c}10(1.6 \%) \\
624(98.4 \%)\end{array}$ & $\begin{array}{c}21(2.1 \%) \\
996(97.9 \%)\end{array}$ & 0.307 \\
\hline $\begin{array}{l}\text { Lung disease } \\
\text { Yes } \\
\text { No }\end{array}$ & $\begin{array}{l}42(31.6 \%) \\
91(68.4 \%)\end{array}$ & $\begin{array}{l}53(21.2 \%) \\
197(78.8 \%)\end{array}$ & $\begin{array}{c}92(14.5 \%) \\
542(85.5 \%)\end{array}$ & $\begin{array}{l}187(18.4 \%) \\
830(81.6 \%)\end{array}$ & $<0.001 *$ \\
\hline $\begin{array}{l}\text { Respiratory } \\
\text { failure } \\
\text { Yes } \\
\text { No }\end{array}$ & $\begin{array}{c}5(3.8 \%) \\
128(96.2 \%)\end{array}$ & $\begin{array}{c}9(3.6 \%) \\
24 \mid(96.4 \%)\end{array}$ & $\begin{array}{c}7(1.1 \%) \\
627(98.9 \%)\end{array}$ & $\begin{array}{c}21(2.1 \%) \\
996(97.9 \%)\end{array}$ & $0.02 I^{*}$ \\
\hline
\end{tabular}

(Continued) 
Table 2 (Continued).

\begin{tabular}{|c|c|c|c|c|c|}
\hline Comorbidities & $\begin{array}{c}\text { Non-Operative Group } \\
\text { (Group A) }(n=133)\end{array}$ & $\begin{array}{l}\text { Delayed Surgery Group } \\
\text { (Group B) }(n=250)\end{array}$ & $\begin{array}{l}\text { Acute Surgery Group } \\
\text { (Group C) }(n=634)\end{array}$ & Total $(n=1,017)$ & $p$-value ${ }^{a}$ \\
\hline $\begin{array}{l}\text { Hepatobiliary } \\
\text { disease } \\
\text { Yes } \\
\text { No }\end{array}$ & $\begin{array}{c}4(3.0 \%) \\
129(97.0 \%)\end{array}$ & $\begin{array}{c}8(3.2 \%) \\
242(96.8 \%)\end{array}$ & $\begin{array}{c}14(2.2 \%) \\
620(97.8 \%)\end{array}$ & $\begin{array}{c}26(2.6 \%) \\
991(97.4 \%)\end{array}$ & 0.659 \\
\hline $\begin{array}{l}\text { Digestive system } \\
\text { disease } \\
\text { Yes } \\
\text { No }\end{array}$ & $\begin{array}{c}4(3.0 \%) \\
129(97.0 \%)\end{array}$ & $\begin{array}{c}4(1.6 \%) \\
246(98.4 \%)\end{array}$ & $\begin{array}{c}16(2.5 \%) \\
618(97.5 \%)\end{array}$ & $\begin{array}{c}24(2.4 \%) \\
993(97.6 \%)\end{array}$ & 0.624 \\
\hline $\begin{array}{l}\text { Renal dysfunction } \\
\text { Yes } \\
\text { No }\end{array}$ & $\begin{array}{c}6(4.5 \%) \\
127(95.5 \%)\end{array}$ & $\begin{array}{c}13(5.2 \%) \\
237(94.8 \%)\end{array}$ & $\begin{array}{c}29(4.6 \%) \\
605(95.4 \%)\end{array}$ & $\begin{array}{c}48(4.7 \%) \\
969(95.3 \%)\end{array}$ & 0.918 \\
\hline $\begin{array}{l}\text { Tumor } \\
\text { Yes } \\
\text { No }\end{array}$ & $\begin{array}{c}2(1.5 \%) \\
|3|(98.5 \%)\end{array}$ & $\begin{array}{c}7(2.8 \%) \\
243(97.2 \%)\end{array}$ & $\begin{array}{c}12(1.9 \%) \\
622(98.1 \%)\end{array}$ & $\begin{array}{c}21(2.1 \%) \\
996(97.9 \%)\end{array}$ & 0.616 \\
\hline $\begin{array}{l}\text { Hypoproteinemia } \\
\text { Yes } \\
\text { No }\end{array}$ & $\begin{array}{l}22(16.5 \%) \\
111(83.5 \%)\end{array}$ & $\begin{array}{l}58(23.2 \%) \\
192(76.8 \%)\end{array}$ & $\begin{array}{l}\text { I53 (24.1\%) } \\
48 \mid(75.9 \%)\end{array}$ & $\begin{array}{l}233(22.9 \%) \\
784(77.1 \%)\end{array}$ & 0.165 \\
\hline
\end{tabular}

Notes: Values are presented as number (\%). ${ }^{*} p<0.05$, statistical significance. ${ }^{a} p$ - values are the results of Pearson chi-square tests.

patients with surgical delay. Precisely because of our national conditions so that we can provide a large amount of delayed surgery data for our research.

In this study, several medical comorbidities are proved to be the major causes of surgical delay, as well as the higher ASA-grade. For which, clinicians need to optimize their physical condition before surgery. Our data also revealed that patients with severe comorbidities of cerebrovascular disease, arrhythmia, heart failure, lung disease, and respiratory failure were usually treated non-operatively.

With the concept of HBL put forward, ${ }^{13}$ a number of researchers ${ }^{3,14,15}$ found that there is a significant amount of potential blood loss after hip fractures which is usually ignored. Previous work has shown the mean decrease in $\mathrm{Hb}$ level between blood taken on admission and discharge is $16 \mathrm{~g} / \mathrm{L}$, with an excess of up to 6-times that observed during the surgical procedure. ${ }^{3,16}$ However, it should be noted that the Gross formula is a linear model for circulating PBV by using the perioperative change of Hct, hence the first post-injury Hct is one of the most important reference indexes to calculate the real HBL. In the current study, we excluded 187 patients who had an admission delay of more than 48 hours to calculate the accuracy of HBL by ensuring the blood routine at the time of admission. In this cohort study, the median volume of HBLmax in non-operative group, delayed surgery group and acute surgery group were $584.1 \mathrm{~mL}$, $780.8 \mathrm{~mL}$, and $649.2 \mathrm{~mL}$, respectively $(p<0.001)$, indicating that surgery by IMF (PFNA) actually accounts for only $11-34 \%$ of the increase of HBLmax. As we know, allogenic blood transfusion is commonly used to treat anemia but involves inherent risks that may worsen outcomes, which is still controversial in the current studies. $^{3,7}$ According to our study, the difference of blood transfusion rates among the three groups did not reach statistical significance.

Male patients, unstable fracture, and blood transfusion volume were identified that have strong influences on HBLmax. Our study also highlights a few findings. It is noteworthy that, although significant differences in ASA grade and some comorbidities were detected among groups, it did not significantly correlate with HBLmax. Another finding relates to the significant increase of HBLmax in patients with delayed surgery compared with patients who received non-operatively treatment, which could be explained by the fact that patients with delayed surgery were associated with increased blood transfusion rate and total blood transfusion volume. 
Table 3 The Maximum Hidden Blood Loss Calculated During Hospitalization, Perioperative Hemoglobin Values, Operation-Related Data, and Transfusion Data of I,0I7 Patients with Intertrochanteric Fractures ${ }^{\mathrm{a}}$

\begin{tabular}{|c|c|c|c|c|c|}
\hline Variables & $\begin{array}{l}\text { Non-Operative Group } \\
\text { (Group A) }(n=133)\end{array}$ & $\begin{array}{l}\text { Delayed Surgery Group } \\
\text { (Group B) }(n=250)\end{array}$ & $\begin{array}{l}\text { Acute Surgery Group } \\
\text { (Group C) }(n=634)\end{array}$ & Total $(n=1,0 \mid 7)$ & $p$-value ${ }^{b}$ \\
\hline$H_{B L} \max , m L I Q R$ & $584.1(407.1,875.7)$ & $780.8(5|0.7|,,|3| .8)$ & $649.2(453.3,972.1)$ & $662.3(457.5,1,010.6)$ & $<0.001 *$ \\
\hline \multicolumn{6}{|l|}{ Hb values, $g / L$} \\
\hline $\mathrm{Hb}_{\mathrm{adm}}$ & $105.3 \pm 20.8^{c}$ & $106.6 \pm 21.4^{c}$ & $110.8 \pm 17.9$ & $109.0 \pm 19.3$ & $0.001 *$ \\
\hline $\mathrm{Hb}_{\text {low }}$ & $93.8 \pm 18.2$ & $90.9 \pm 16.8$ & $94.8 \pm 15.2^{d}$ & $93.7 \pm 16.1$ & $0.005^{*}$ \\
\hline $\mathrm{Hb}_{\text {dis }}$ & $106.7 \pm 14.7$ & $104.0 \pm 13.2$ & $104.2 \pm 12.4$ & $104.5 \pm 12.9$ & 0.112 \\
\hline $\mathrm{Hb}$ decrease between & $11.7(0,61.7)$ & $15.7(0,65.1)^{\mathrm{e}}$ & $16.0(0,71.6)^{\mathrm{e}}$ & $15.4(0,71.6)$ & $0.002 *$ \\
\hline $\mathrm{Hb}_{\mathrm{adm}}$ and $\mathrm{Hb}_{\text {low }}$ & & & & & \\
\hline $\begin{array}{l}\mathrm{Hb} \text { decrease between } \\
\mathrm{Hb}_{\mathrm{adm}} \text { and } \mathrm{Hb}_{\mathrm{dis}}\end{array}$ & $-1.4(-86.1,61.7)^{c}$ & $2.6(-60.7,62.7)^{c}$ & $6.5(-61.2,54.0)$ & $4.5(-86.1,62.7)$ & $<0.001 *$ \\
\hline \multicolumn{6}{|l|}{$\begin{array}{l}\text { Operation-related } \\
\text { data }\end{array}$} \\
\hline ASA grade, $\mathrm{n}(\%)$ & & & & & $<0.001 *$ \\
\hline 1 & $8(6.0 \%)$ & $22(8.8 \%)$ & $103(16.2 \%)$ & $133(13.1 \%)$ & \\
\hline II & $35(26.3 \%)$ & $88(35.2 \%)$ & 274 (43.2\%) & 397 (39.0\%) & \\
\hline III & 46 (34.6\%) & $108(43.2 \%)$ & 191 (30.1\%) & 345 (33.9\%) & \\
\hline IV & $4 \mid(30.8 \%)$ & $25(10.0 \%)$ & $60(9.5 \%)$ & $126(12.4 \%)$ & \\
\hline$\vee$ & $3(2.3 \%)$ & $7(2.8 \%)$ & $6(0.9 \%)$ & $16(1.6 \%)$ & \\
\hline $\begin{array}{l}\text { Bone traction before } \\
\text { surgery, } n(\%)\end{array}$ & & & & & $<0.001 *$ \\
\hline No & 100 (75.2\%) & 179 (71.6\%) & 529 (83.4\%) & 808 (79.4\%) & \\
\hline Yes & $33(24.8 \%)$ & 7I (28.4\%) & 105 (16.6\%) & 209 (20.6\%) & \\
\hline $\begin{array}{l}\text { Duration of } \\
\text { operation, min }\end{array}$ & NA & $105.4 \pm 35.6$ & $99.6 \pm 34.0$ & $101.2 \pm 34.5$ & $0.025^{*}$ \\
\hline $\begin{array}{l}\text { Method of anesthesia, } \\
\text { n (\%) }\end{array}$ & & & & & 0.116 \\
\hline General anesthesia & NA & $98(39.2 \%)$ & $296(46.7 \%)$ & 394 (44.6\%) & \\
\hline Spinal anesthesia & NA & 25 (10.0\%) & 50 (7.9\%) & 75 (8.5\%) & \\
\hline $\begin{array}{l}\text { Combined spinal-epidural } \\
\text { anesthesia }\end{array}$ & NA & 127 (50.8\%) & 288 (45.4\%) & 415 (46.9\%) & \\
\hline $\begin{array}{l}\text { Intra-operative blood } \\
\text { loss, mL IQR }\end{array}$ & NA & $200(150,400)$ & $100(200,300)$ & $100(200,300)$ & $0.001 *$ \\
\hline \multicolumn{6}{|l|}{$\begin{array}{l}\text { Red blood cell } \\
\text { transfusion }\end{array}$} \\
\hline Yes & 93 (69.9\%) & 195 (78\%) & 455 (71.8\%) & $743(73.1 \%)$ & 0.116 \\
\hline No & $40(30.1 \%)$ & $55(22 \%)$ & 179 (28.2\%) & 274 (26.9\%) & \\
\hline $\begin{array}{l}\text { Blood transfusion } \\
\text { volume, units IQR }\end{array}$ & $2(0,4)^{d}$ & $4(2,6)$ & $2(0,4)^{d}$ & $2(0,6)$ & $0.001 *$ \\
\hline
\end{tabular}

Notes: Plus-minus values are means \pm SD. ${ }^{*} p<0.05$, statistical significance. ${ }^{a}$ Values are presented as the means \pm SD for normally distributed data; $\mathrm{HBL}$ max and blood transfusion volume are presented as the median (interquartile range); Two variables of perioperative hemoglobin decreased values and intra-operative blood loss are presented as the median (range); ASA grade, bone traction before surgery, method of anesthesia, and red blood cell transfusion is presented as the number (\%). All the red blood cells transfusions are assumed to contain the same number of cells and a unit of red blood cells is approximately $200 \mathrm{~mL}$. ${ }^{\mathrm{b}} \mathrm{In} \mathrm{Hb}_{\mathrm{adm}}, \mathrm{Hb}_{\mathrm{low}}$, and $\mathrm{Hb}_{\mathrm{dis}}$, $\mathrm{p}$-values are the results of ANOVA tests on mean. In $\mathrm{HBL}_{\max }$, $\mathrm{Hb}$ drop between admission and the lowest recorded, Hb drop between admission and discharge and blood transfusion volume, $p$-values are the results of Kruskal-Wallis $\mathrm{H}$-tests on median. In ASA grade, bone traction before surgery, method of anesthesia, and red blood cell transfusion, $p$-value are the results of Pearson chi-square tests. In duration of operation, $p$-value is the result of two independent sample $t$-test on mean. In intra-operative blood loss, $p$-value is the result of Wilcoxon rank-sum test on median. 'Significant differences in statistics compared with group C. ${ }^{d}$ Significant differences in statistics compared with

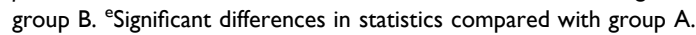

Abbreviations: HBL, hidden blood loss; ASA, American Society of Anesthesiologists; Hb, hemoglobin; IQR, interquartile range. 
Table 4 Multiple Linear Regression Analysis of Association Between Risk Factors and the Maximum Hidden Blood Loss Calculated During Hospitalization in 1017 Patients

\begin{tabular}{|c|c|c|c|c|}
\hline Variables $^{\mathrm{a}}$ & $\beta$ & $\mathbf{B}^{\prime}$ & $95 \% \mathrm{Cl}$ & $p$-value \\
\hline Constant & 386.237 & & $(288.221,484.253)$ & $<0.00 I^{*}$ \\
\hline Male & 198.139 & 0.229 & $(141.215,238.974)$ & $<0.00 I^{*}$ \\
\hline Age & -1.760 & -0.036 & $(-4.870,1.350)$ & 0.267 \\
\hline Unstable fracture & 197.314 & 0.233 & (149.56I, 245.068) & $<0.001^{*}$ \\
\hline \multicolumn{5}{|l|}{ ASA-grade } \\
\hline 2 & 32.547 & 0.039 & $(-41.013,106.106)$ & 0.385 \\
\hline 3 & 72.321 & 0.084 & $(-3.498,148.140)$ & 0.062 \\
\hline 4 & 18.435 & 0.015 & $(-75.828,112.699)$ & 0.701 \\
\hline 5 & 144.980 & 0.044 & $(-50.24 \mathrm{I}, 340.20 \mathrm{I})$ & 0.145 \\
\hline Violent injury & -4.204 & -0.002 & $(-152.713,144.304)$ & 0.956 \\
\hline Bone traction before surgery & 30.871 & 0.030 & $(-28.447,90.189)$ & 0.307 \\
\hline \multicolumn{5}{|l|}{ BMI } \\
\hline Overweight $\left(24 \leq \mathrm{BMI}<28 \mathrm{~kg} / \mathrm{m}^{2}\right)$ & 57.685 & 0.065 & $(6.515,108.854)$ & $0.027^{*}$ \\
\hline Obesity $\left(\mathrm{BMI} \geq 28 \mathrm{~kg} / \mathrm{m}^{2}\right)$ & 97.989 & 0.070 & $(16.261,179.716)$ & $0.019 *$ \\
\hline \multicolumn{5}{|l|}{ Grouping } \\
\hline Group B & 122.312 & 0.128 & $(41.786,202.838)$ & $0.003 *$ \\
\hline Group C & 68.708 & 0.081 & $(-3.201,140.617)$ & 0.061 \\
\hline \multicolumn{5}{|l|}{ Method of anesthesia } \\
\hline Spinal anesthesia & -5.885 & -0.004 & $(-1 \mid 4.631,102.862)$ & 0.915 \\
\hline Combined spinal-epidural anesthesia & 16.027 & 0.020 & $(-42.609,74.663)$ & 0.592 \\
\hline Duration of operation & -0.336 & -0.029 & $(-1.262,0.591)$ & 0.477 \\
\hline Intra-operative blood loss & -0.087 & -0.034 & $(-0.294,0.120)$ & 0.411 \\
\hline Blood transfusion volume & 21.822 & 0.228 & $(16.327,27.317)$ & $<0.00 I^{*}$ \\
\hline \multicolumn{5}{|l|}{ Comorbidities } \\
\hline Hypertension & 16.172 & 0.020 & $(-35.2 \mid 2,67.557)$ & 0.537 \\
\hline Diabetes & 36.972 & 0.039 & $(-18.301,92.244)$ & 0.190 \\
\hline Coronary heart disease & 2.546 & 0.003 & $(-54.131,59.224)$ & 0.930 \\
\hline Carotid plaque/atherosclerosis & -2.553 & -0.003 & $(-59.916,54.81 I)$ & 0.930 \\
\hline Cerebrovascular disease & -34.057 & -0.039 & $(-88.779,20.665)$ & 0.222 \\
\hline Delirium & -36.920 & -0.021 & $(-140.276,66.437)$ & 0.483 \\
\hline Arrhythmia & -28.046 & -0.023 & $(-99.083,42.991)$ & 0.439 \\
\hline Myocardial infarction & 75.858 & 0.033 & $(-58.472,210.188)$ & 0.268 \\
\hline Heart failure & -9.902 & -0.005 & $(-137.800,117.995)$ & 0.879 \\
\hline Valvular heart disease & 102.928 & 0.034 & $(-68.813,274.669)$ & 0.240 \\
\hline Lung disease & -7.148 & -0.007 & $(-70.802,56.506)$ & 0.826 \\
\hline Respiratory failure & -54.919 & -0.019 & $(-240.032,130.194)$ & 0.561 \\
\hline Hepatobiliary disease & 31.705 & 0.012 & $(-116.029,179.439)$ & 0.674 \\
\hline Digestive system disease & 47.396 & 0.018 & $(-105.221,200.012)$ & 0.542 \\
\hline Renal dysfunction & -11.257 & -0.006 & $(-125.816,103.30 I)$ & 0.847 \\
\hline Tumor & -26.176 & -0.009 & $(-193.585,|4| .233)$ & 0.759 \\
\hline Hypoproteinemia & 45.051 & 0.046 & $(-18.025,108.127)$ & 0.161 \\
\hline
\end{tabular}


Table 4 (Continued).

\begin{tabular}{|l|c|c|c|c|}
\hline Variables $^{\mathbf{a}}$ & $\boldsymbol{\beta}$ & $\mathbf{B}^{\prime}$ & $\mathbf{9 5 \%} \mathbf{C l}$ & \\
\hline DVT & & & $\mathbf{P}^{\text {-value }}$ \\
Intermuscular vein thrombosis & 25.355 & 0.030 & $(-24.721,75.430)$ \\
Posterior tibial vein thrombosis & 112.614 & 0.070 & $(19.240,205.987)$ & 0.321 \\
Popliteal vein thrombosis & -38.236 & -0.015 & $(-183.269,106.796)$ & $0.018^{*}$ \\
Superficial femoral vein thrombosis & -18.188 & -0.006 & $(-193.940,157.564)$ & 0.605 \\
Common femoral vein thrombosis & 0.758 & 0.000 & $(-139.202,140.718)$ & 0.839 \\
\hline
\end{tabular}

Notes: ${ }^{*} p<0.05$, statistical significance. ${ }^{a}$ In the multi-category variables, ASA-grade I, normal BMI, no DVT, and patients in conservative treatment group (group A) were chosen as standard, others were converted into dummy variables.

Abbreviations: ASA, American Society of Anesthesiologists; BMI, body mass index; DVT, deep venous thrombosis.

Smith et $\mathrm{al}^{14}$, and $\mathrm{Li}$ et $\mathrm{al}^{17}$ conjectured in their survey that the majority of blood loss actually occurred before surgery. According to our data, the peak of HBL was observed to appear at days 5-7 in most patients of this cohort. Chechik et $\mathrm{al}^{15}$ found HBL was significantly increased with early operative treatment. A possible explanation for this might be that surgery was performed earlier than the peak of coagulation, since a transient hypercoagulable state was demonstrated to peak at the fifth day after severe trauma. ${ }^{18}$ Whereas in a systematic review of literature, Spahn ${ }^{19}$ showed anemia was more common in post-operation, reaching $87 \pm 10 \%$. However, the cases involved in that study received surgical treatment prior to the peak of HBL. Therefore, conclusions from previous literature $^{3,15,19}$ that the surgery by IMF increased the HBL might wrongly attribute the cause to IMF since a large proportion of patients received surgery within 48 hours (before the peak of coagulation).

Previous studies revealed that $45.6 \%$ of emergency surgical patients had anemia ${ }^{20}$ and unexplained anemia accounts for about one-third in these patients, which can be a catastrophic event precipitating a steep decline in health and independence. ${ }^{7,19}$ Similarly, we found $22.8 \%$ of patients have anemia (with $\mathrm{Hb}$ value less than $10 \mathrm{~g} / \mathrm{L}$ ) at hospital admission and a prevalence of $22.9 \%$ was observed in surgical patients prior to the operation. At

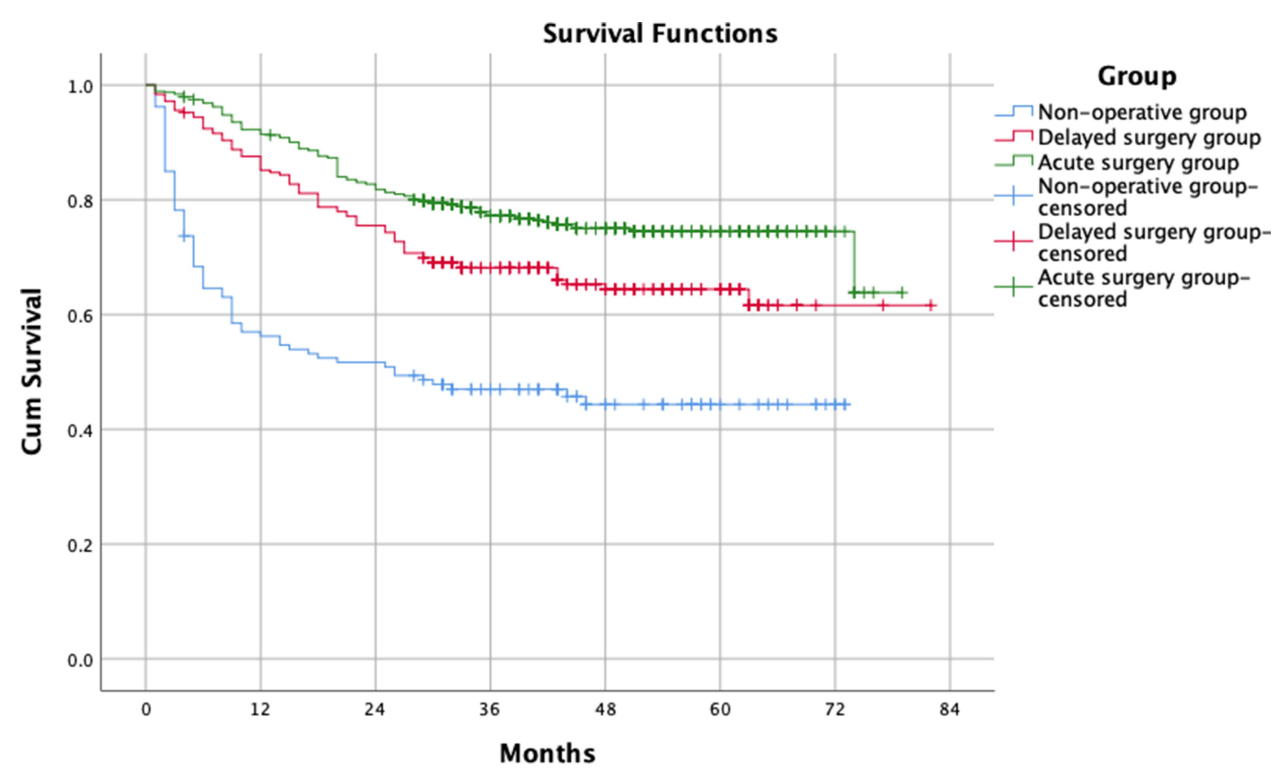

Figure 2 Kaplan-Meier survival curves for elderly patients with intertrochanteric fractures. The Kaplan-Meier survival curve of patients without surgery was significantly lower than that of surgical patients ( $p<0.00 \mathrm{I}$, log-rank). Within I year after injury, patients treated nonoperatively had a risk of death at I month that was 3.2 -times as high, a risk of death at 3 months that was 6.6-times as high, a risk of death at 6 months that was 8.2-times as high, a risk of death at 9 months that was 5.3 -times as high, and a risk of death at 12 months that was 4.2-times as high as the risk compared with the patients who received operations. Higher mortality was also obtained in patients with surgical delay than acute surgery patients ( $p=0.00$ I, log-rank). 
the time of last $\mathrm{Hb}$ levels measured before discharge, there were still $35.8 \%$ of patients classified as anemia.

The overall mortality rates have been well studied and reported to vary from $12-35 \%$ in the first year and up to $10 \%$ of patients die postoperatively in hospital even with treatment. ${ }^{15,21,22}$ However, evidence in the literature for long-term survival analysis in a relatively large size cohort is scant. By the end of our 6-year follow-up study, 30.1\% were dead and most were treated nonoperatively, which is consistent with the previous studies that such non-operative therapy should only be considered in moribund patients with severe comorbidities, placing them at risk for surgery and anesthesia. $^{23,24}$ We found patients without surgery had a rapid decline of cumulative survival rate in the first year while, for patients who received operations, the decline mainly occurred in the first 2 years, which merits careful attention of family members for better care.

The strength of this study is that it includes the HBL calculated by serial of Hct values, not by using a given day after surgery or the final record before discharge, although widely used in previous literature. ${ }^{3,15,25}$ Another strength is the single internal fixation we used and standardized perioperative intervention, which minimizes the risk of sampling bias. Finally, the cohort comprised a relatively large number of patients with a long-term follow-up. The limitations to this study include its retrospective design and the data being collected in a single center. Finally, although we controlled many variables and comorbidities related to health status, endogeneity bias from other omitted variables may affect the results of the current study.

\section{Conclusion}

HBL is the main component of total blood loss of patients with intertrochanteric fracture and it is more likely to result from initial trauma rather than the surgery. Intertrochanteric fracture treated with IMF does not cause a large amount of HBL.

\section{Abbreviations}

PFNA, proximal femoral nail anti-rotation; HBL, hidden blood loss; IMF, intramedullary fixation; BMI, body mass index; ASA, American Society of Anesthesiologists; DVT, deep venous thrombosis; PBV, patient blood volume; TRCL, total red cell loss volume; TBL, total perioperative blood loss.

\section{Data Sharing Statement}

The dataset generated and/or analyzed during the current study is not publicly available due to patient-related confidentiality, but it is available from the corresponding author on reasonable request.

\section{Ethics Approval and Informed Consent}

This study was approved by the institutional review board of the third Hospital of Hebei Medical University in compliance with the Declaration of Helsinki and consent was waived for this non-interventional, observational, and retrospective study, in which the patient data used were kept strictly confidential.

\section{Acknowledgments}

We thank Yujia Yuan, Pengyu Ye, and Mingming Jia for data collection for this study.

\section{Author Contributions}

All authors contributed to the data analysis, drafting or revising of the article, have agreed on the journal to which the article will be submitted, gave final approval of the version to be published, and agree to be accountable for all aspects of the work.

\section{Funding}

The study was financially supported by National Key R\&D Program of China (No.2019YFC0120600) and the 2019 Hebei Provincial Department of Finance Geriatric Disease Prevention and Control Funds.

\section{Disclosure}

All authors report no conflicts of interest in this work.

\section{References}

1. Geraci A, Martorana U. The treatment of intertrochanteric fractures of the femur with Endovis nail. Ortop Traumatol Rehabil. 2011;13 (6):565-572. doi:10.5604/15093492.971041

2. Johnell OKJ, Kanis JA. An estimate of the worldwide prevalence, mortality and disability associated with hip fracture. Osteoporos Int. 2004;15(11):897-902. doi:10.1007/s00198-004-1627-0

3. Foss NB, Kehlet H. Hidden blood loss after surgery for hip fracture. $J$ Bone Jt Surg. 2006;88-B:1053-1059. doi:10.1302/0301-620X.8 $8 \mathrm{~B} 8.17534$

4. Marsh JL, Slongo TF, Agel J, et al. Fracture and dislocation classification compendium - 2007: orthopaedic trauma association classification, database and outcomes committee. J Orthop Trauma. 2007;21(10 Suppl):S1-133. doi:10.1097/00005131-200711101-00001 
5. Menon S, Kelly AM. How accurate is weight estimation in the emergency department? Emerg Med Australas. 2005;17(2):113-116. doi:10.1111/j.1742-6723.2005.00701.x

6. Carson JL, Terrin ML, Noveck H, et al. Liberal or restrictive transfusion in high-risk patients after hip surgery. $N$ Engl J Med. 2011;365 (26):2453-2462. doi:10.1056/NEJMoa1012452

7. Partridge J, Harari D, Gossage J, Dhesi J. Anaemia in the older surgical patient: a review of prevalence, causes, implications and management. J R Soc Med. 2013;106(7):269-277. doi:10.1177/ 0141076813479580

8. Nadler SB, Hidalgo JH, Bloch T. Prediction of blood volume in normal human adults. Surgery. 1962;51(2):224-232.

9. Gross JB. Estimating allowable blood loss: corrected for dilution. Anesthesiology. 1983;58(3):277-280. doi:10.1097/00000542198303000-00016

10. Bretherton CP, Parker MJ. Early surgery for patients with a fracture of the hip decreases 30-day mortality. Bone Joint J. 2015;97-b (1):104-108. doi:10.1302/0301-620X.97B1.35041

11. Buse GL, Bhandari M, Sancheti P, et al. Accelerated care versus standard care among patients with hip fracture: the HIP ATTACK pilot trial. Can Med Assoc J. 2014;186(1):E52-60.

12. White SM, Griffiths R, Holloway J, Shannon A. Anaesthesia for proximal femoral fracture in the UK: first report from the NHS hip fracture anaesthesia network. Anaesthesia. 2010;65(3):243-248. doi:10.1111/j.1365-2044.2009.06208.x

13. Sehat KR, Evans R, Newman JH. How much blood is really lost in total knee arthroplasty? Correct blood loss management should take hidden loss into account. Knee. 2000;7(3):151-155. doi:10.1016/ S0968-0160(00)00047-8

14. Smith GH, Tsang J, Molyneux SG, White TO. The hidden blood loss after hip fracture. Injury. 2011;42(2):133-135. doi:10.1016/j. injury.2010.02.015

15. Chechik O, Thein R, Fichman G, Haim A, Tov TB, Steinberg EL. The effect of clopidogrel and aspirin on blood loss in hip fracture surgery. Injury. 2011;42(11):1277-1282. doi:10.1016/j.injury.2011.01.011
16. Nadia Rosencher HEMK, Menichella G, Menichella G, Menichella G. Abraham for the OSTHEO investigation. Orthopedic surgery transfusion hemoglobin European overview (OSTHEO) study: blood management in elective knee and hip arthroplasty in Europe. Transfusion. 2003;43(4):459-469. doi:10.1046/j.1537-2995.2003.00348.x

17. Li B, Li J, Wang S, Liu L. Clinical analysis of peri-operative hidden blood loss of elderly patients with intertrochanteric fractures treated by unreamed proximal femoral nail anti-rotation. Sci Rep. 2018;8 (1):3225. doi: $10.1038 / \mathrm{s} 41598-018-21703-4$

18. Sumislawski JJ, Kornblith LZ, Conroy AS, Callcut RA, Cohen MJ. Dynamic coagulability after injury: is delaying venous thromboembolism chemoprophylaxis worth the wait? J Trauma Acute Care Surg. 2018;85(5):907-914. doi:10.1097/TA.0000000000002048

19. Spahn DR. Anemia and patient blood management in hip and knee surgery: a systematic review of the literature. Anesthesiology. 2010;113(2):482-495. doi:10.1097/ALN.0b013e3181e08e97

20. Gruson KI, Aharonoff GB, Egol KA, Zuckerman JD, Koval KJ. The relationship between admission hemoglobin level and outcome after hip fracture. J Orthop Trauma. 2002;16(1):39-44. doi:10.1097/ 00005131-200201000-00009

21. Roth T, Kammerlander C, Gosch M, Luger TJ, Blauth M. Outcome in geriatric fracture patients and how it can be improved. Osteoporos Int. 2010;21(Suppl 4):S615-619. doi:10.1007/s00198-010-1401-4

22. Brauer CA, Coca-Perraillon M, Cutler DM, Rosen AB. Incidence and mortality of hip fractures in the United States. JAMA. 2009;302 (14):1573-1579. doi:10.1001/jama.2009.1462

23. Handoll HH, Parker MJ. Conservative versus operative treatment for hip fractures in adults. Cochrane Database Syst Rev. 2008;(3):Cd000337.

24. Parker MJ, Handoll HH. Conservative versus operative treatment for extracapsular hip fractures. Cochrane Database Syst Rev. 2000;(2): Cd000337.

25. Miao K, Ni S, Zhou X, et al. Hidden blood loss and its influential factors after total hip arthroplasty. J Orthop Surg Res. 2015;10(1):36. doi:10.1186/s13018-015-0185-9
Clinical Interventions in Aging

\section{Publish your work in this journal}

Clinical Interventions in Aging is an international, peer-reviewed journal focusing on evidence-based reports on the value or lack thereof of treatments intended to prevent or delay the onset of maladaptive correlates of aging in human beings. This journal is indexed on PubMed Central, MedLine, CAS, Scopus and the Elsevier

\section{Dovepress}

Bibliographic databases. The manuscript management system is completely online and includes a very quick and fair peer-review system, which is all easy to use. Visit http://www.dovepress.com/ testimonials.php to read real quotes from published authors. 